\title{
GAMBARAN STATUS GIZI ANAK KELAS VI DI SEKOLAH DASAR MIFTAKHUL ULUM SURABAYA
}

\author{
Novera Herdiani, Wiwik Afridah \\ Fakultas Kesehatan Universitas Nahdlatul Ulama Surabaya \\ e-mail: novera.herdiani@unusa.ac.id
}

\begin{abstract}
Background, nutritional status is a description of balance between the need of nutrients for keeping a good life, to maintenance normal body function also energy production in one side and the consumption of nutrients in the other. Children in elementary school are the best target for improvement of community nutrition because in the childhood the function of the brain organ began to form so the development of intelligence is quite rapid. Lack of nutritional intake in children can inhibit the physical growth and thinking ability in children and subsequently reduce in learning interest. Therefore the nutritional status of the children must detect immediately to carry out the preventive measurements. Objective, the purpose of this study is to know the nutritional status of children at grade VI in elementary school Miftakhul Ulum Surabaya based on height and weight. Methods, this study is a quantitative descriptive using survey method, weighting index instrument by height in children aged 6-17 years old from Health Department in 2011. This study used the measurement of body weight and height. Subjects of this study were all students at grade VI in elementary school Miftakhul Ulum Surabaya, which amount 81 children. Data collecting techniques use anthropometric measurements which include measurement of body weight and height then calculated base of data analysis techniques using quantitative descriptive with percentage. Result, study results showed most of the students were 12 years old $(56.80 \%)$, mostly male $(55.60 \%)$. most of them have body height $130-140 \mathrm{~cm}(37.00 \%)$, and body weight $31-40 \mathrm{~kg}(46,90 \%)$. Male children have more problems with their nutritional status (51.10\%). Male children much often have underweight and over weight (13.30\%) than girls. By the increasing their age, their BMI will be normal category (100\%). By the age of 13 and 14 years old, the children will not have underweight $(0 \%)$. Conclusion, based on the nutritional status of all children at grade VI, it can be concluded that the nutritional status of children at grade VI in elementary school Miftakhul Ulum Surabaya is in underweight category (very thin and lean) with percentage $56.80 \%$. While the normal weight percentage $32.10 \%$, and over weight (fat and obesity) with percentage $11.10 \%$.
\end{abstract}

Keywords: nutritional status, children at grade VI, elementary school

\section{PENDAHULUAN}

Pencapaian pembangunan kesehatan dinilai dengan derajat kesehatan masyarakat. Derajat kesehatan digambarkan dengan situasi mortalitas, morbiditas, dan status gizi masyarakat. Ketidakseimbangan gizi dapat menurunkan kualitas SDM. Gizi yang baik akan menghasilkan SDM yang berkualitas yaitu sehat, cerdas dan memiliki fisik yang tangguh serta produktif (Departemen Gizi dan Kesehatan Masyarakat, 2013). Perbaikan gizi diperlukan mulai dari masa kehamilan, bayi dan anak balita, prasekolah, anak usia sekolah dasar, remaja dan dewasa, sampai usia lanjut (Gibson RS, 2005). Anak sekolah dasar merupakan sasaran strategis dalam perbaikan gizi masyarakat karena pada masa anak fungsi organ otak mulai terbentuk mantap sehingga perkembangan kecerdasan cukup pesat. Anak Sekolah Dasar (SD) adalah anak usia 6-12 tahun (Depkes, 2011).

Pertumbuhan dan perkembangan anak sangat membutuhkan gizi yang cukup agar tidak 
terjadi penyimpangan pada pertumbuhan dan perkembangan anak. Gizi yang kurang akan membuat sistem imun pada anak lemah. Aktivitas yang cukup tinggi dan kebiasaan makan yang tidak teratur pada anak sering mengakibatkan ketidakseimbangan antara asupan dan kecukupan gizi (Ipriyona Tri Noli, 2011). Ketidakseimbangan antara asupan dan kecukupan gizi akan menimbulkan masalah gizi, baik itu masalah gizi lebih maupun gizi kurang. Kekurangan gizi juga dapat menyebabkan penyakit infeksi yang menjadi penyebab kematian. Kelebihan gizi dapat menyebabkan obesitas pada anak (Supariasa, dkk., 2002).

Berdasarkan data Riskesdas tahun 2013, prevalensi kurus (menurut IMT/U) pada anak umur 5-12 tahun adalah 11,2\%, terdiri dari 4,0\% sangat kurus dan 7,2\% kurus. Prevalensi kurus pada umur 13-15 tahun adalah 11,1\% terdiri dari 3,3\% sangat kurus dan 7,8\% kurus. Sedangkan menurut data Riskesdas 2010 sebelumnya yaitu prevalensi anak pendek pada anak usia 6-12 tahun adalah 35,8\%, dan untuk anak kurus pada usia 6-12 tahun adalah 11\%. Tidak hanya masalah gizi kurang, masalah gizi lebih juga harus diperhatikan karena prevalensi gizi lebih meningkat dengan bertambahnya usia. Secara nasional masalah gemuk pada anak umur 5-12 tahun masih tinggi yaitu 18,8\%, terdiri dari gemuk $10,8 \%$ dan sangat gemuk (obesitas) 8,8\%. Prevalensi gemuk pada umur 13-15 tahun di Indonesia sebesar 10,8\%, terdiri dari 8,3\% gemuk dan 2,5\% sangat gemuk (obesitas). Sebanyak 13 provinsi dengan prevalensi gemuk di atas nasional, termasuk provinsi Jawa Timur (Badan Penelitian dan Pengembangan Kesehatan Kementerian Kesehatan RI, 2013).

Gambaran kondisi wilayah yang akan dijadikan sasaran penelitian yaitu: SD Miftakhul Ulum, beralamatkan di Jl. Rungkut tengah III/
13, Kecamatan Gunung Anyar, Kota Surabaya, Provinsi Jawa Timur. Secara sosial, masyarakat berada di tengah-tengah perkampungan dengan status sosial masyarakatnya memiliki pendidikan yang cukup. Secara ekonomi: masyarakat di sekitar termasuk pada golongan ekonomi menengah. Secara lingkungan, di sekitar sekolah berhadapan dengan satu TK dan dikelilingi oleh rumah-rumah penduduk sehingga banyak rumah yang membuka toko di rumahnya, karena tidak adanya kantin di sekolah, sehingga banyak anak yang tidak memperhatikan makanan dan kesehatan, serta belum pernah dilakukan pengukuran tinggi badan dan berat badan.

Berkaitan dengan fenomena di atas, maka perlu adanya penelitian mengenai gambaran status gizi anak usia sekolah di SD Miftakhul Ulum Surabaya, sehingga status gizi anak dapat diketahui dengan segera untuk dilakukan langkah preventif.

\section{METODE}

Penelitian ini merupakan penelitian deskriptif kuantitatif. Metode penelitian menggunakan survei dengan teknik pengukuran antropometri dan pengukuran tinggi badan dan berat badan dilaksanakan pada bulan Juni 2015.

Variabel penelitian ini adalah penggambaran keadaan status gizi siswa SD Miftakhul Ulum Surabaya. Definisi operasional status gizi adalah gambaran keseimbangan antara kebutuhan akan zat gizi untuk pemeliharaan kehidupan, pemeliharaan fungsi normal tubuh dan untuk produksi energi satu pihak serta konsumsi zat gizi di lain pihak. Pengukuran penelitian ini yaitu menggunakan antropometri tinggi badan dan berat badan. Status gizi dapat ditentukan melalui pemeriksaan secara antropometri dengan Indeks Masa Tubuh (IMT), dengan pengukuran berat badan dengan 
satuan kilogram $(\mathrm{kg})$ dan pengukuran tinggi badan (TB) dengan satuan meter (m), dengan rumus sebagai berikut (Depkes, 2011):

IMT $=\frac{\text { Berat Badan }(\mathrm{kg})}{\text { Tinggi Badan }(\mathrm{m}) \mathrm{X} \text { Tinggi Badan }(\mathrm{m})}$

Subjek dalam penelitian ini adalah seluruh siswa kelas VI SD Miftakhul Ulum Surabaya yang berjumlah 81 anak.

Instrumen penelitian menggunakan pengukuran berat badan dan tinggi badan kemudian dikonsultasikan berdasarkan kategori perhitungan indeks berat badan menurut tinggi badan pada anak usia 6-17 tahun (Depkes, 2011). Teknik pengumpulan data menggunakan pengukuran antropometri yang meliputi pengukuran berat badan dan tinggi badan kemudian dihitung dengan berdasarkan perhitungan indeks berat badan menurut tinggi badan pada anak usia 617 tahun kemudian diberikan penjelasan mengenai proses pelaksanaan pengukuran berat badan dan tinggi badan, kemudian anak-anak dipandu untuk melaksanakan pengukuran.

Penelitian ini menggunakan teknik analisis deskriptif persentase untuk mengetahui gambaran tentang status gizi dengan mengukur berat badan dengan satuan kilogram (kg) dan tinggi badan dengan satuan meter (m) kemudian dihitung dengan tabel berdasarkan penghitungan indeks berat badan menurut tinggi badan pada anak usia 5-18 tahun dengan merujuk dari Departemen Kesehatan Republik Indonesia tahun 2011. Kemudian untuk menentukan status gizi menurut Keputusan Menteri Kesehatan Republik Indonesia Nomor: 1995/MENKES/SK/ XII/2010 tentang standar antropometri penilaian status gizi anak Kementerian Kesehatan RI Direktorat Jenderal Bina Gizi dan Kesehatan Ibu dan Anak Direktorat Bina dan Gizi tahun 2011 dengan kriteria sebagai berikut.
Tabel 1 Status Gizi dan Indeks (BB/U)

\begin{tabular}{|l|l|l|}
\hline \multicolumn{1}{|c|}{ Indeks } & \multicolumn{1}{c|}{$\begin{array}{c}\text { Kategori } \\
\text { Status Gizi }\end{array}$} & \multicolumn{1}{c|}{ Ambang Batas } \\
\hline Indeks Massa & Sangat kurus & $<-3$ SD \\
\cline { 2 - 3 } Tubuh Menurut & Kurus & -3SD sampai dengan -2SD \\
\cline { 2 - 3 } Umur (IMT/U) & Normal & -2SD sampai dengan 1SD \\
\cline { 2 - 3 } Anak umur 5-18 & Gemuk & $>$ 1SD sampai dengan 2SD \\
\cline { 2 - 3 } Tahun & Obesitas & $>$ 2SD \\
\hline
\end{tabular}

Sumber: Buku Depkes, 2011

Setelah data diperoleh selanjutnya data dianalisis untuk menarik kesimpulan dari penelitian yang telah dilakukan. Untuk menganalisis data digunakan teknik analisis statistik dengan persentase, dengan rumus sebagai berikut.

$\mathrm{P}=\frac{\mathrm{F} \times 100 \%}{\mathrm{~N}}$

Keterangan:

$\mathrm{P}=$ Persentase

$\mathrm{F}=$ Frekuensi

$\mathrm{N}=$ Jumlah Seluruh Siswa

\section{HASIL}

\section{Berat Badan Anak Kelas VI}

Hasil analisis berat badan siswa menunjukkan bahwa berat badan subjek memiliki nilai minimal $21 \mathrm{~kg}$ dan maksimal $80 \mathrm{~kg}$ dengan rerata 39,69 kg, Range $(\mathrm{R})=80-21=59$. Jumlah Kelas (K) ditentukan sebanyak 6. Oleh karena itu nilai Interval $(\mathrm{I})=\mathrm{R} / \mathrm{K}=59 / 6=9,8$.

Tabel 2 Distribusi Frekuensi Berat Badan Anak Kelas VI

\begin{tabular}{|c|c|c|c|}
\hline No. & Berat Badan & Frekuensi & Persentase \\
\hline 1. & $21-30 \mathrm{~kg}$ & 15 & 18,50 \\
\hline 2. & $31-40 \mathrm{~kg}$ & 38 & 46,90 \\
\hline 3. & $41-50 \mathrm{~kg}$ & 15 & 18,50 \\
\hline 4. & $51-60 \mathrm{~kg}$ & 6 & 7,40 \\
\hline 5. & $61-70 \mathrm{~kg}$ & 6 & 7,40 \\
\hline 6. & $71-80 \mathrm{~kg}$ & 1 & 1,30 \\
\hline \multicolumn{2}{|r|}{ Total } & 81 & 100,00 \\
\hline
\end{tabular}


Berdasarkan tabel 2 menunjukkan bahwa sebagian besar anak kelas VI SD Miftakhul Ulum Surabaya dengan berat badan antara 31$40 \mathrm{~kg}$ memiliki frekuensi sebesar 38 anak (46,90\%). Adapun jumlah frekuensi terkecil adalah pada interval berat badan 71-80 kg dengan frekuensi 1 anak (1,30\%). Secara frekuensi data berat badan anak kelas VI dapat dilihat pada gambar 1 berikut.

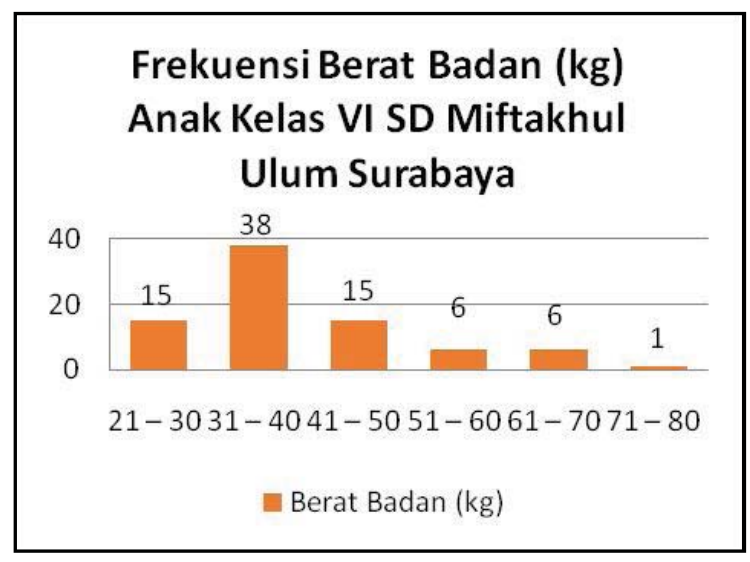

Gambar 1 Diagram Batang Berat Badan Anak Kelas VI

\section{Tinggi Badan Anak Kelas VI}

Hasil analisis tinggi badan siswa menunjukkan bahwa tinggi badan subjek memiliki nilai minimal $130 \mathrm{~cm}$ dan maksimal $170 \mathrm{~cm}$ dengan rerata $144,87 \mathrm{~cm}$, Range $(\mathrm{R})=170-130=40$. Jumlah Kelas $(\mathrm{K})$ ditentukan sebanyak 4. Oleh karena itu nilai Interval $(\mathrm{I})=\mathrm{R} / \mathrm{K}=40 / 4=10$. Tabel distribusi frekuensi tinggi badan siswa adalah sebagai berikut.

Tabel 3 Distribusi Frekuensi Tinggi Badan Anak Kelas VI

\begin{tabular}{|c|c|c|c|}
\hline No. & Tinggi Badan & Frekuensi & Persentase \\
\hline 1. & $130-140 \mathrm{~cm}$ & 30 & 37,00 \\
\hline 2. & $140-150 \mathrm{~cm}$ & 27 & 33,33 \\
\hline 3. & $150-160 \mathrm{~cm}$ & 19 & 23,50 \\
\hline 4. & $160-170 \mathrm{~cm}$ & 5 & 6,20 \\
\hline \multicolumn{2}{|c|}{ Total } & 81 & 100,00 \\
\hline
\end{tabular}

Berdasarkan Tabel 3 terlihat bahwa sebagian besar siswa memiliki tinggi badan di antara 130-140 cm dengan frekuensi sebesar 30 anak (37\%). Adapun jumlah frekuensi terkecil adalah pada interval tinggi badan $160-170 \mathrm{~cm}$ dengan frekuensi 5 anak (6,20\%). Secara grafik frekuensi data tinggi badan anak kelas VI dapat dilihat pada Gambar 2 berikut.

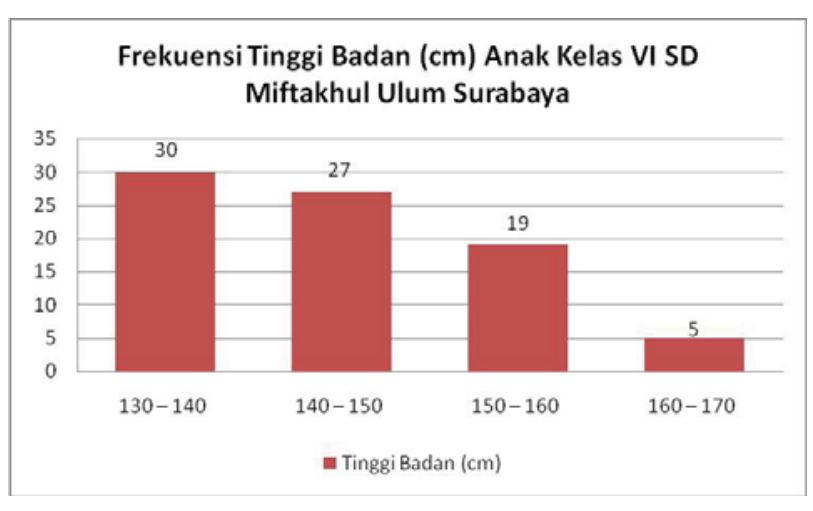

\section{Status Gizi Anak Kelas VI}

Hasil penelitian tentang status gizi anak kelas VI SD Miftakhul Ulum Surabaya diketahui dengan pengukuran tinggi badan dan berat badan siswa. Hasil pengukuran status gizi adalah sebagai berikut.

Tabel 4 Status Gizi Anak Kelas VI

\begin{tabular}{|c|c|c|c|c|c|c|c|c|c|}
\hline \multirow{3}{*}{ No. } & \multirow{3}{*}{$\begin{array}{c}\text { Jenis } \\
\text { Kelamin }\end{array}$} & \multicolumn{6}{|c|}{ Kategori } & \multirow{2}{*}{\multicolumn{2}{|c|}{ Total }} \\
\hline & & \multicolumn{2}{|c|}{$\begin{array}{l}\text { BB Rendah } \\
\text { (Sangat } \\
\text { Kurus dan } \\
\text { Kurus) }\end{array}$} & \multicolumn{2}{|c|}{$\begin{array}{l}\text { BB Normal } \\
\text { (Normal) }\end{array}$} & \multicolumn{2}{|c|}{$\begin{array}{l}\text { BB Berlebih } \\
\text { (Gemuk dan } \\
\text { Obesitas) }\end{array}$} & & \\
\hline & & $\mathbf{N}$ & $\%$ & $\mathbf{N}$ & $\%$ & $\mathbf{N}$ & $\%$ & $\mathbf{N}$ & $\%$ \\
\hline 1. & Laki-laki & 23 & 28,40 & 16 & 19,80 & 6 & 7,40 & 45 & 55,60 \\
\hline 2. & Perempuan & 23 & 28,40 & 10 & 12,30 & 3 & 3,70 & 36 & 44,40 \\
\hline & Total & 46 & 56,80 & 26 & 32,10 & 9 & 11,10 & 81 & 100,00 \\
\hline
\end{tabular}

Berdasarkan Tabel 4, terlihat bahwa status gizi anak kelas VI SD Miftakhul Ulum Surabaya berada pada kategori berat badan rendah (sangat kurus dan kurus) dengan persentase 56,80\%, berat badan normal (normal) 32,10\%, dan berat badan berlebih (gemuk dan obesitas) 11,10\%. Pada siswa laki-laki maupun perempuan kategori 
status gizi yang dominan adalah berat badan rendah (sangat kurus dan kurus) dengan persentase pada siswa laki-laki dan perempuan 28,40\%. Secara visual status gizi anak kelas VI adalah sebagai berikut.

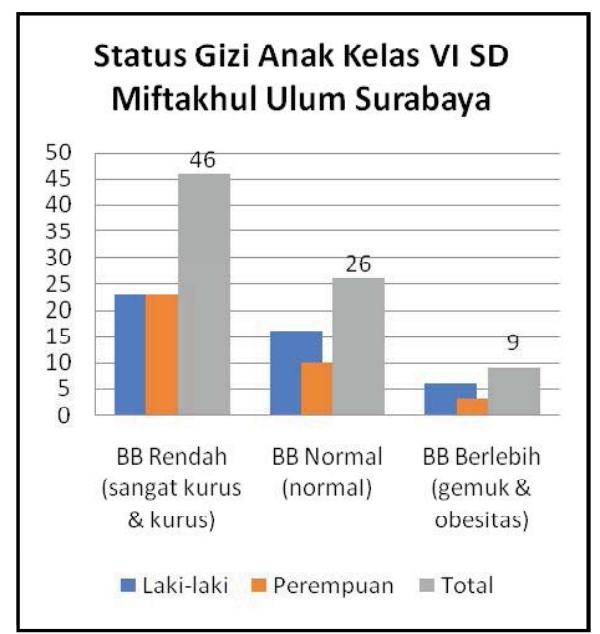

Gambar 3 Diagram Batang Status Gizi Anak Kelas VI

\section{Hasil Analisis Data Umur dengan Penilaian BMI}

Tabel 5 Umur dengan Penilaian BMI

\begin{tabular}{|c|c|c|c|c|c|c|c|c|c|}
\hline \multirow{3}{*}{ No. } & \multirow{3}{*}{$\begin{array}{l}\text { Umur } \\
\text { Peserta }\end{array}$} & \multicolumn{6}{|c|}{ Penilaian BMI } & \multirow{2}{*}{\multicolumn{2}{|c|}{ Total }} \\
\hline & & \multicolumn{2}{|c|}{$\begin{array}{l}\text { BB Rendah } \\
\text { (Sangat } \\
\text { Kurus dan } \\
\text { Kurus) }\end{array}$} & \multicolumn{2}{|c|}{$\begin{array}{c}\text { BB Normal } \\
\text { (Normal) }\end{array}$} & \multicolumn{2}{|c|}{$\begin{array}{c}\text { BB Berlebih } \\
\text { (Gemuk dan } \\
\text { Obesitas) }\end{array}$} & & \\
\hline & & $\mathbf{N}$ & $\%$ & $\mathbf{N}$ & $\%$ & $\mathbf{N}$ & $\%$ & $\mathbf{N}$ & $\%$ \\
\hline 1. & 11 tahun & 18 & 58,10 & 11 & 35,50 & 2 & 6,50 & 31 & 100,00 \\
\hline 2. & 12 tahun & 28 & 60,90 & 12 & 26,10 & 6 & 13,00 & 46 & 100,00 \\
\hline 3. & 13 tahun & 0 & 0,00 & 2 & 66,70 & 1 & 33,30 & 3 & 100,00 \\
\hline 4. & 14 tahun & 0 & 0,00 & 1 & 100,00 & 0 & 0,00 & 1 & 100,00 \\
\hline $\begin{array}{l}\text { Pears } \\
\text { Alfa }\end{array}$ & $\begin{array}{l}\text { hi-Squar } \\
=0,05\end{array}$ & & $s i=$ & & & & & & \\
\hline
\end{tabular}

Berdasarkan Tabel 5 dapat diperoleh informasi bahwa umumnya semakin bertambahnya usia maka BMI anak tersebut akan memasuki kategori normal (100\%). Menjelang usia 13 dan 14 tahun, anak-anak tidak mengalami berat badan yang rendah (0\%). Dengan semakin bertambah usia, diharapkan anak-anak mampu memahami asupan yang dimakan. Memperhatikan kandungan gizi yang dimakan serta aturan- aturan dalam mengonsumsi sesuatu serta tidak lupa untuk senantiasa beraktivitas agar tidak terjadi penimbunan lemak.

\section{Hasil Analisis Data Jenis Kelamin dengan Peni- laian BMI}

Tabel 6 Jenis Kelamin dengan Penilaian BMI

\begin{tabular}{|c|c|c|c|c|c|c|c|c|c|}
\hline \multirow{3}{*}{ No. } & \multirow{3}{*}{$\begin{array}{c}\text { Jenis } \\
\text { Kelamin } \\
\text { Peserta }\end{array}$} & \multicolumn{6}{|c|}{ Penilaian BMI } & \multirow{2}{*}{\multicolumn{2}{|c|}{ Total }} \\
\hline & & \multicolumn{2}{|c|}{$\begin{array}{l}\text { BB Rendah } \\
\text { (Sangat } \\
\text { Kurus dan } \\
\text { Kurus) }\end{array}$} & \multicolumn{2}{|c|}{$\begin{array}{c}\text { BB Normal } \\
\text { (Normal) }\end{array}$} & \multicolumn{2}{|c|}{$\begin{array}{c}\text { BB } \\
\text { Berlebih } \\
\text { (Gemuk } \\
\text { dan } \\
\text { Obesitas) }\end{array}$} & & \\
\hline & & $\mathbf{N}$ & $\%$ & $\mathbf{N}$ & $\%$ & $\mathbf{N}$ & $\%$ & $\mathbf{N}$ & $\%$ \\
\hline 1. & Laki-laki & 23 & 51,10 & 16 & 35,60 & 6 & 13,30 & 45 & 100,00 \\
\hline 2. & Perempuan & 23 & 63,90 & 10 & 27,80 & 3 & 8,30 & 36 & 100,00 \\
\hline
\end{tabular}

Berdasarkan Tabel 6 menunjukkan bahwa umumnya anak laki-laki lebih memiliki masalah pada status gizinya (51,105). Anak laki-laki sering mengalami berat badan rendah dan juga mengalami berat badan berlebih daripada anak perempuan. Lemak tubuh anak perempuan dan anak laki-laki berbeda. Karena itu untuk anakanak tersedia dua grafik yang berbeda untuk perempuan dan laki-laki. BMI anak laki-laki pada masa pra-sekolah menurun dan sejalan dengan bertambahnya usia maka BMI-nya meningkat.

\section{PEMBAHASAN}

Hasil penelitian menyimpulkan bahwa status gizi anak kelas VI SD Miftakhul Ulum Surabaya adalah berat badan rendah (56,80\%). Hal ini berarti komposisi tubuh anak berdasarkan berat badan dan tinggi badan sebagian besar adalah sangat kurus dan kurus. Faktor yang memengaruhi status gizi anak kelas VI SD Miftakhul Ulum Surabaya sangat kompleks. Faktor tersebut di antaranya faktor aktivitas fisik anak, 
gizi, faktor psikologis, dan faktor istirahat. Secara keseluruhan status gizi anak kelas VI SD Miftakhul Ulum Surabaya perlu mendapat perhatian. Anak yang memiliki status gizi kurus dan sangat kurus ternyata adalah anak yang memiliki kecenderungan aktivitas fisik yang kurang. Akibatnya otot-otot tubuh anak tidak berkembang dengan baik, sehingga komposisi tubuh pun menjadi tidak ideal (Mathews, 2013).

Beberapa anak di SD juga memiliki status gizi yang gemuk dan obesitas. Anak yang dalam kategori gemuk ternyata memiliki beberapa sebab. Pertama dari faktor genetis ternyata orangtua mereka menderita obesitas. Selain itu pola makan anak juga cenderung tidak terkontrol serta aktivitas fisik anak tersebut pun kurang memadai. Akibatnya karbohidrat yang berada dalam tubuh disimpan menjadi lemak yang mengakibatkan ketidak seimbangan antara berat badan dengan tinggi badan anak (Supariasa, dkk., 2002).

Suhardjo (2012) menyatakan bahwa kemampuan dan hasil belajar selain dipengaruhi oleh ketepatan dalam pemilihan bahan makanan yang kaya akan nutrisi dan kebiasaan diet, juga dipengaruhi status gizi berdasarkan indeks $\mathrm{BB} /$ TB, BB/U, TB/U dan BMI. Pemilihan nutrisi yang tepat dapat mengoptimalkan pertumbuhan dan perkembangan otak. Rendahnya status gizi anak dapat membawa dampak negatif pada peningkatan kualitas sumber daya manusia. Kekurangan gizi kronis berhubungan erat dengan pencapaian akademik murid sekolah yang semakin rendah.

Semakin bertambahnya usia maka BMI anak tersebut akan memasuki kategori normal. Menjelang usia 13 dan 14 tahun, anak-anak tidak mengalami berat badan yang rendah. Dengan semakin bertambah usia, diharapkan anakanak mampu memahami asupan yang dimakan. Memperhatikan kandungan gizi yang dimakan serta aturan-aturan dalam mengonsumsi sesuatu serta tidak lupa untuk senantiasa beraktivitas agar tidak terjadi penimbunan lemak. Sejalan dengan pertumbuhannya, maka lemak tubuh anak-anak berubah dari tahun ke tahun. Interpretasi BMI tergantung kepada usia anak. BMI menurun selama masa pra-sekolah, lalu meningkat pada masa dewasa (Gibson, RS. 2011).

Fase usia sekolah membutuhkan asupan makanan yang bergizi untuk menunjang masa pertumbuhan dan perkembangannya. Selain untuk kebutuhan energi, asupan makanan yang bergizi juga memengaruhi perkembangan otak, apabila makanan tidak cukup mengandung zatzat gizi yang dibutuhkan, dan keadaan ini berlangsung lama, akan menyebabkan perubahan metabolisme otak (Joko Pekik Irianto, 2006).

Anak yang kurang gizi mudah mengantuk dan kurang bergairah yang dapat mengganggu proses belajar di sekolah dan menurun prestasi belajarnya, daya pikir anak juga berkurang karena pertumbuhan otak tidak optimal (Gibney, 2009). Rendahnya status gizi jelas berdampak pada kualitas sumber daya manusia. Oleh karena itu, status gizi merupakan faktor yang memberikan pengaruh cukup besar terhadap prestasi seseorang. Gizi merupakan salah satu faktor penting dalam memberikan kontribusi terhadap kualitas sumber daya manusia (Hadi, 2005).

Asupan gizi yang baik berperan penting dalam mencapai pertumbuhan badan yang optimal. Pertumbuhan badan yang optimal ini mencakup pertumbuhan otak yang sangat menentukan kecerdasan seseorang. Dampak akhir dari konsumsi gizi yang baik dan seimbang adalah meningkatnya kualitas sumber daya manusia (Karyadi, 2006).

Keadaan status gizi dan indeks prestasi merupakan gambaran apa yang dikonsumsi anak sekolah dasar dalam jangka waktu yang lama, dapat berupa gizi kurang maupun gizi lebih. 
Zat-zat gizi seperti karbohidrat, protein, maupun zat gizi lainnya khususnya zat besi, dalam metabolisme tubuh berperan dalam proses berpikir atau proses penalaran serta daya konsentrasi dan sangat berkaitan erat dengan efisiensi belajar (Karyadi, 2006). Dengan keadaan status gizi yang baik diharapkan berdampak pada prestasi belajar yang baik pula pada anak.

\section{KESIMPULAN}

Berdasarkan hasil penelitian yang telah dilakukan dapat disimpulkan sebagai berikut.

1. Anak kelas VI SD Miftakhul Ulum Surabaya dengan jumlah keseluruhan adalah 81 siswa/ siswi. Sebagian besar memiliki tinggi badan 130-140 cm (37,00\%), dan berat badan 31$40 \mathrm{~kg}(46,90 \%)$.

2. Berdasarkan penilaian BMI, status gizi anak Kelas VI SD Miftakhul Ulum Surabaya sebagian besar berada pada kategori berat badan rendah (sangat kurus dan kurus) dengan persentase $56,80 \%$. Sedangkan berat badan normal persentase $32,10 \%$, dan berat badan berlebih (gemuk dan obesitas) dengan persentase $11,10 \%$.

3. Semakin bertambahnya usia maka BMI anak tersebut akan memasuki kategori normal. Anak laki-laki lebih memiliki masalah pada status gizinya. Anak laki-laki sering mengalami berat badan rendah dan juga mengalami berat badan berlebih daripada anak perempuan. BMI anak laki-laki pada masa prasekolah menurun dan sejalan dengan bertambahnya usia maka BMI-nya meningkat.

\section{SARAN}

1. Bagi orangtua agar meningkatkan asupan gizi anak serta mengatur waktu dengan keseim- bangan antara aktivitas fisik, belajar, dan istirahat.

2. Bagi guru agar berperan aktif untuk memberikan kesadaran tentang status gizi bagi siswa.

3. Perlunya menyertakan variabel-variabel bebas yang lain agar diketahui variabel yang dominan dalam memengaruhi status gizi siswa.

\section{DAFTAR RUJUKAN}

Badan Penelitian dan Pengembangan Kesehatan Kementerian Kesehatan RI., (2013) Riset Kesehatan Dasar (RISKESDAS) 2013. Jakarta www.litbang.depkes.go.id/sites/download/rkd2013/Laporan_Riskesdas2013. PDF (sitasi 20 Juli 2015).

Departemen Kesehatan Republik Indonesia. 2011. Pedoman Penyuluhan Gizi pada Anak Sekolah bagi Petugas Penyuluhan. Jakarta: Ditjen Bina Kesehatan Masyarakat Direktorat Gizi Masyarakat.

Departemen Gizi dan Kesehatan Masyarakat. 2013. Gizi dan Kesehatan Masyarakat. Edisi 8. Universitas Indonesia. Jakarta: Rajawali Pers.

Gibney, M. 2009. Gizi Kesehatan Masyarakat. Jakarta: EGC.

Gibson RS. 2005. Principles of Nutritional Assessment. New York: Oxford University Press.

Gibson, RS. 2011. Handouts: Using Dietary Reference Values for Evaluating Nutrient Adequacy for Group. Short Course Nutritional Status Assessment. Jakarta: SEAMEO-RECFON Universitas Indonesia.

Hadi, H. 2005. Beban Ganda Masalah dan Implikasinya terhadap Kebijakan Pembangunan Kesehatan Nasional. Tugas Akhir Gizi. Universitas Surakarta.

Ipriyona Tri Noli. 2011. Hubungan Kebiasaan Makan dengan Status Gizi Anak SD Kelas 
VI di Tiga SD Swasta di Kota Palembang. Skripsi. Jurusan Pendidikan Dokter Umum. Fakultas Kedokteran Universitas Sriwijaya. Joko Pekik Irianto. 2006. Pedoman Gizi Lengkap Keluarga dan Olahragawan. Yogyakarta: Penerbit Andi.

Karyadi, D. 2006. Kecukupan Gizi yang Dianjurkan. Jakarta: Gramedia Pustaka Utama.
Mathews. 2013. Measurement in Physical Education Philadelphia. London: WB Sounders. Suhardjo, Clara M. Kusharto. 2012. PrinsipPrinsip Ilmu Gizi. Yogyakarta: Kanisius. Supariasa I Dewa Nyoman, Bachyar Bakri, Ibnu Fajar. 2002. Penilaian Status Gizi. Ed. 2. Jakarta: EGC. 